\title{
Place branding's present and past realities, and future research agendas
}

Dominic Medway, Gary Warnaby and John Byrom

\section{How and why we arrived here}

Around two years ago, the publisher Edward Elgar approached us and asked if we were interested in editing a new collected volume for their Research Agendas series on 'place branding'. It was a surprise, as our track record on this subject is one in which we have been critical of the concept. The arguments in this regard are well rehearsed. In essence, we have at various times suggested that place branding, and wider place marketing, emerges far too often as a top-down management activity, which largely sidesteps citizens' viewpoints, rather than a bottom-up approach which includes them (Warnaby and Medway, 2013). This accords with other ongoing dialogues amongst scholars regarding the level of inclusiveness of the place branding process, particularly in terms of residents' involvement (see, for example, Braun et al., 2013).

The criticisms of place branding do not end here. For example, whilst on the one hand place branding might be viewed as a purely rational management act fuelled by market forces around supposed place competitiveness, some have argued that place branding is not as innocent as some like to think of it and observations on the current state of the discipline make any critical researcher engage in serious wonderings around place brands and their effects on places and the people that live in them' (Lichrou et al., 2018: 1). In this regard, actions undertaken to supposedly enhance the place brand, such as altering the place name itself (Medway and Warnaby, 2014), are likely to have significant political repercussions. Linked to this, others, such as Oliveira and Ashworth (2017), have indicated that place branding remains overly embedded in the mindsets of management and marketing, whilst lacking sensitivity and openness to 
multiple disciplinary viewpoints like planning, architecture, social policy, transport development and sustainability.

Elsewhere, we have been particularly reproving of much of the literature on place branding for its obsession with measurement (see Medway and Warnaby, 2017), such as assessing supposed place brand 'personality' through the numeric values people attach to places in relation to various identified human characteristics - e.g. stylishness, creativity, optimism and tolerance (see, for example, Kaplan et al., 2010). Of course, as soon as you start to measure things in this manner, then a logical next step is to compare the results of this process, irrespective of whether they make much sense - it is an approach that delivers outcomes such as the Anholt Ipsos Nation Brand Index, which ranks nations according to a brand score made up of key measures across six dimensions. ${ }^{1}$ We have argued that such mindless metricisation represents the very worst of place branding and presents a reductive view of place, ${ }^{2}$ in which:

the views of those engaged with the places in question are boiled down to mere numbers relating to attributes, which have typically been pre-determined in closed survey questions. A glaring omission in such enquiry is that it ignores the fact that places are experienced at a multisensory level by those within them, be they tourists, residents, visitors, or other place stakeholders. This phenomenological understanding of place interaction is absent in a positivist world of scale developments that are used to objectively further our 'understanding' of place brands and place branding activity. (Medway and Warnaby, 2017: 151)

All of the above critiques of place branding, in which we have clearly been active and willing participants, provides some background on the manner in which we have arrived to the point of editing this book (or the 'how'), but it does not explain the 'why'. Specifically, why as authors with an evident critical perspective on place branding were we asked by the publishers if we would compile a volume on its future research agendas; and, perhaps even more perplexing for some readers, why did we agree to do it? The answer to the first of these questions probably comes down to the mordant reality that others had already been asked and refused, but we, after some consideration, didn't - the publisher was honest enough to intimate as much, but we feel our academic egos can cope with being the last (and only) men (three of them in this case) standing... you take what you can get, etc. If you are reading this and thinking (à la $\mathrm{Brando}^{3}$ ) that 'I was asked first and I coulda' been a contender', then we can only apologise for acquiescing so readily to the publisher's request to edit this book; which brings us right back to that second question of why we actually did. It is certainly something we thought carefully about, and on which we came to the following conclusion and justification. It appears we have spent several years, probably a decade or so in fact, looking in from time to time 
on the practice of place branding, and the enthusiastic scholarship that surrounds it, and, like some other scholars highlighted above, assuming a rather externalised and disparaging viewpoint upon such activity. The opportunity to edit this book, therefore, was a chance to enter into the place branding fold and shake things up a bit; the rationale being if you don't like something very much then it is best to question it from within if you wish to shift perspectives and understanding. Put otherwise, and to paraphrase former United States President Lyndon Johnson, we thought we should accept the challenge of working inside the place branding 'tent' for a change, rather than standing outside it and 'pissing in'.

With this approach in mind, the original brief for the book which we circulated to potential authors invited them to explore ideas and debates they thought could inform the future of research in place branding. In so doing, we encouraged the interplay of oppositional perspectives, ranging from those who see place branding as a potential means of improving the economic vitality and viability of places, to others who might consider much existing place branding activity as exclusionary to certain sectors of society and, thereby, politically divisive. Capturing such a diversity of standpoints emphasised a need to open contributions out to the widest possible range of subject areas. We therefore welcomed authorship from a range of discipline areas, including (but not limited to): marketing, geography, planning, management and tourism. Sifting through the contributor biographies at the start of this book, one can see that we were lucky and privileged enough to attain this breadth of scholarship. And, with chapter authors and subjects finalised by the early autumn of 2019, the wind was set fair for a seamless delivery of first drafts in the early spring of 2020 - and then Covid-19 struck...

\section{Present and past realities}

It is surely a truism that there are few aspects of human endeavour that are not in some way affected by the current Covid-19 pandemic; and there is no obvious reason why place branding would be an exception to that. As draft chapters started to ping into our email inbox in April 2020, as editors we had already started to question whether a book on place branding had much relevance anymore. In short order, one of the principal reasons to enact place branding is to attract potential income streams to the place in question, whether this is in the form of tourist visits and their associated spend, or inward investment and development by organisations, institutions and other bodies outwith the place. Covid-19 has radically changed both these worlds. 
Regarding tourism, for example, a recent report by McKinsey (Constantin et al., 2020) has suggested that international tourist arrivals could plunge by 60 to 80 per cent in 2020 across the globe, and that tourism spending is not likely to return to pre-Covid-19 levels until 2024, putting up to 120 million jobs at risk. The challenges of overtourism in popular and previously crowded locations like Venice have seemingly evaporated, only to be replaced by concerns from governments, those who live in tourist destinations, and even potential tourists themselves, about the risks that tourism brings for an accelerated spread of the virus. Tourist attractions (art galleries, museums, theatres, historic buildings and sites, etc.) remain closed or under tight restrictions on visitor numbers to ensure social distancing. And, in some instances, the welcome given to visitors by local communities living in tourist hotspots has even turned to hostility with, for example, the UK press reporting how visitors to Cornwall in July 2020 were greeted with a handmade banner on the A30, one of the main roads into the county, telling them to 'Turn around and fuck off. This is the kind of reputational 'stink bomb' that no place manager needs when trying to nurture their destination's positive image, and it explains why the chief executive of Visit Cornwall, Malcolm Bell, called the sign 'offensive and unforgivable' (Mathers, 2020). In terms of tourism, then, place branding has lost some of its raison d'être; if tourists do not want to visit, and in cases of Covid-19 restrictions and lockdowns may not even be allowed to do so, then perhaps part of the notion of a place brand becomes a little redundant.

Turning to inward investment, a key driver of this is large organisations tapping into new customer bases and labour forces, but certainly where the service sector is concerned, Covid-19 has exposed the fact that the necessity for these fixed ties to place has reduced in importance - at least for now. White-collar workers have learnt to rapidly adapt to virtual and footloose modes of working, and have embraced a whole host of video conferencing technologies and networking platforms to achieve this (e.g. MS Teams, Zoom, Adobe Connect, etc.). This is not a disappearance of those industrial agglomerations or spatial clusterings of like-minded firms and service providers which economic geographers have long talked about as a means by which collaborative, creative and productive synergies emerge to create 'local buzz' (see, for example, Bathelt et al., 2004; Pinch et al., 2003); rather it is a migration of those clusterings towards a mode of spatiality where the relational assumes greater importance than the Cartesian, and where an employee's position in (virtual) industrial networks of human interaction holds greater influence than the location from which they work. However, this does not bode well for the place branding of the world's major service centres, where the financial and legal sectors dominate. Indeed, one only has to look at the challenges London is facing, with empty streets and unused ancillary services (sandwich and coffee 
shops, taxi drivers, dry cleaners) now that much of the work on which the city's economy is built is being conducted from home offices and kitchen tables around the UK and Europe (see, for example, Partridge, 2020), and with many employees seemingly reluctant to venture back into their former workplace geographies, mobilities and routines (Nikolic, 2020).

Whilst the above challenges make the future for place branding look potentially bleak, there are perhaps two fundamental considerations to bear in mind that make the activity itself, as well as a forward-facing research agenda on the topic, worthy of discussion in a book such as this. The first observation is that nothing lasts forever, and it is as inevitable as sunrise that we will eventually emerge from Covid-19 to a future in which tourism will once again thrive, and where inward investment will again be important; it is simply that the basis on which these things occur may look very different to how it has been previously. In this regard, it is often helpful to take lessons from history, and we would like to take readers back to the 1937 Exposition Internationale des Arts et Techniques dans la Vie Moderne (International Exposition of Art and Technology in Modern Life) held in Paris, France from 25 May to 25 November 1937 (see Figure 1.1).

In many ways the 1937 Paris Exposition was a place or nation branding exercise writ large: a host of countries from across the globe exhibited impressive, purpose-built pavilions displaying their nation's achievements and prowess in art and technology. But the event was dominated by the large Soviet and German pavilions, which faced each other in front of the Eiffel Tower. The former was topped by a massive statue of a male worker and a female peasant (Worker and Kolkhoz Woman by Vera Mukhina), their hands aloft holding a hammer and a sickle. Directly opposite, the imposing tower of the German pavilion had been designed by Hitler's architect Albert Speer to be slightly higher, so that the Nazi symbols of the eagle and swastika looked down on this monument to communism (see Figure 1.1). The event arguably symbolised how thin the line between nation branding and unfettered nationalism can become, and was a clear harbinger of the imminence and devastation of World War II. Yet from that war, for all its misery, death and destruction, a new world order emerged in which the globalised flow and integration of financial and human capital (workers, tourists, etc.), and associated wealth, grew for many nations. In such a climate, place branding has had an important and largely positive role to play, far removed from the sinister nationalistic sabre rattling of the 1937 Paris Exposition. 

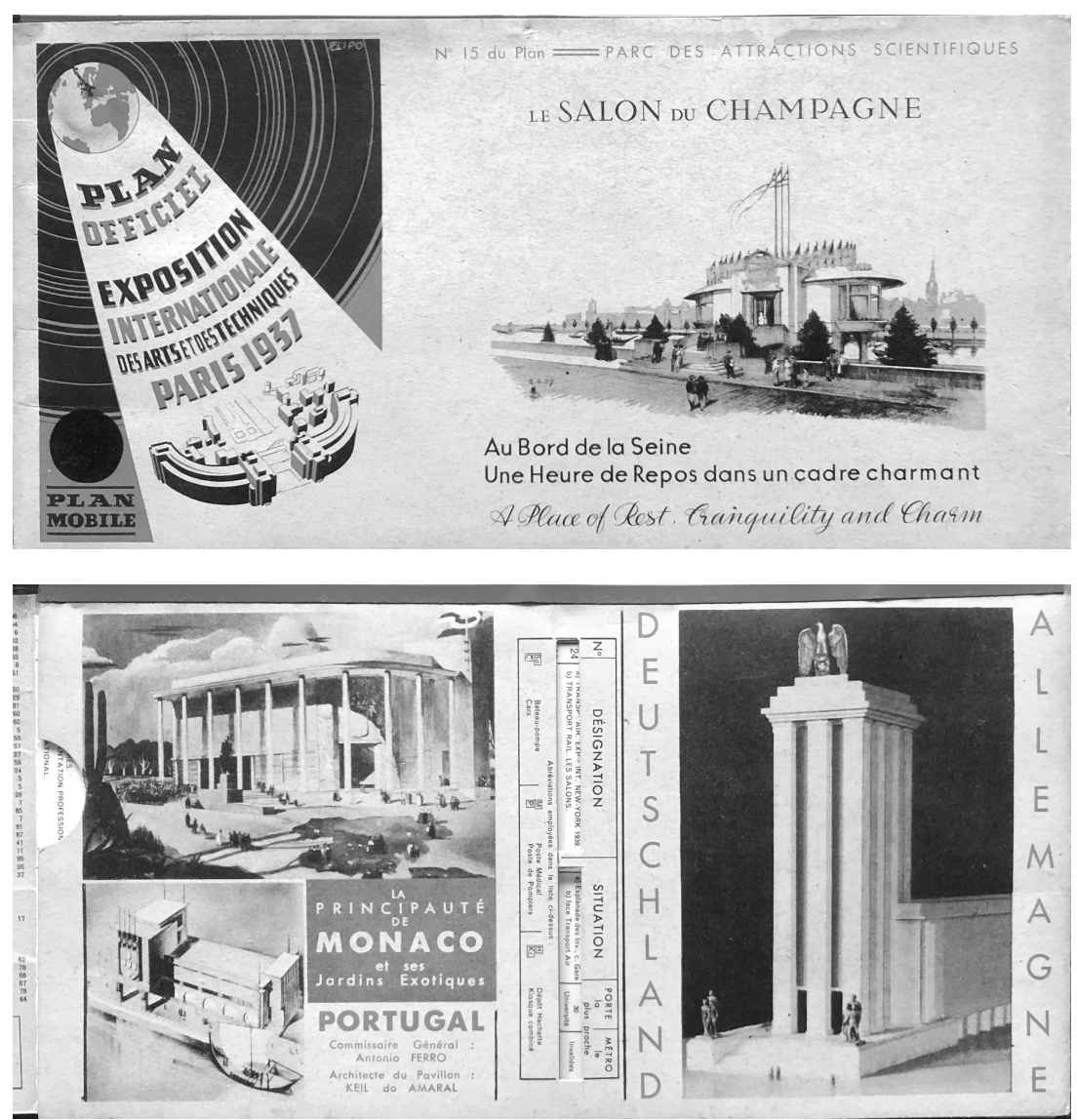

Source: Images kindly loaned from the 'museum_of_stuff' on Instagram.

Figure 1.1 Images of the official plan for the 1937 International Exposition of Art and Technology in Modern Life, Paris

Rather like World War II, Covid-19 appears to have again brought humanity to another critical point in history at which the 'reset buttons' for all different forms of public diplomacy (place branding included) are activated, and from which such activities are likely to emerge in a different form to how they were before - a so-called 'new normal'. In discussing a research agenda for place branding, which is by necessity future oriented, it is reassuring to see, therefore, that three of the chapters in this book mention and consider the impact of Covid-19 (Campelo, Keegan and Oliveira et al.), albeit very briefly in the latter two instances. This is especially impressive as the virus was not even 
on the radar when these authors agreed to write these chapters. Beyond this, many of the topics discussed throughout this book as part of a future research agenda for place branding have the potential for a high level of relevance in a post-Covid-19 world.

This brings us to our second point, which is that place branding in a post-Covid-19 context has the potential to be as important as it ever was; it is simply that the audience for its execution and effort may need major reconsideration. In the past, it is perhaps fair to say that much place branding has had an external focus, working across national or regional boundaries to attract attention, reputation and the inflow of human and financial capital. But in a world where international movement and associated air travel is falling away as people 'stay local' for work and tourism, we perhaps need to think about the potential to switch place branding efforts closer to home. As noted above, previous research has considered the importance of place branding campaigns having the involvement of residents in terms of determining how a place is defined and represented, but perhaps such local populations now need to be the principal focus of those campaigns too. In the UK, for example, the news media is awash with stories of people (re)discovering 'hidden gems' and the attraction, beauty and excitement of where they live under lockdown (Ivey, 2020), as well as embracing the benefits of a 'staycation' (Monk, 2020). It feels as if place branding has an important role to play in helping us to 'mainline' this resurgence of topophilia (Tuan, 1974) and 'bring dwelling to the fullness of its nature' (Heidegger, 2001: 159). Put more simply, this is about humanity learning to better appreciate and (re)connect with where we live. Home, after all, is where the heart is, and that is just as well as it looks as if we will all be spending much more time there in a post-Covid-19 future. Place branding, it seems, could have an important role to play in helping citizens nurture their feelings of local embeddedness, place attachment, care and associated safety and security. Accordingly, it seems timely and appropriate that scholars might use the unwelcome opportunity of this significant episode in history (a global health crisis with a geographical scope and impact not seen since the $1918 \mathrm{flu}$ pandemic, and before that probably the Black Death of 1346 to 1353) to step back and survey the academic landscape of place branding to this point in time, before turning to (re)consider the direction(s) place branding practice might now take and the future research agendas this establishes. This is exactly what this book hopes to achieve. 


\section{Future research agendas}

Deciding how an edited book should be structured, and how the various contributions could hang together, is always an interesting challenge, and especially so as we encouraged our contributors to write about pretty much anything they felt had relevance to a future research agenda for place branding. Nevertheless, the initial abstracts potential contributors submitted revealed some broad, albeit porous, boundaries that could be drawn between the various proposed chapter topics. From this stage onwards four parts of the book started to emerge: the first on issues of place branding 'governance', the second covering different place branding 'contexts', the third concerned with matters of 'experience' and place branding and the fourth and final part addressing place branding and 'creativity'.

Transitioning between the abstract submission stage of the editorial process to the receipt and review of the final draft chapters, our view on titles and order of parts did not really change. This was largely because of the rigorous manner in which contributors stuck to their original chapter proposals. This reassured us of the potential coherence of the book, and that sense of positivity was further reinforced by the excellent quality of writing in the first drafts of the chapters we received. In this regard, overseeing and nurturing the development of an edited academic volume can often be a fairly thankless task, with contributions of very variable (and sometime dubious) scholarly and narrative quality being a common challenge. We can honestly say this was never the case with this book, and from start to finish it was a pleasure to work with the contributing authors, all of whom are well established or up-and-coming scholars in their fields.

\section{Governance}

In Part I, the order of play sets off with Aram Eisenschitz's chapter (Chapter 2), 'Place branding and the neoliberal class settlement'. This takes a politically oriented and overtly critical approach to place branding, arguing that it is not just a means of helping cities become more competitive, but is also an aspect of the class settlement in which neoliberalism displaced social democracy. Thus, he argues that place branding does not just sell places by changing their image, but actively engages in the political transformation of cities as well as displaying many of the assumptions of that settlement which help to legitimate it. Incorporating vignettes of place branding, including London's South Bank and Canary Wharf, Glasgow, New York and the Great Exhibition, Aram argues that we should evaluate the impacts of place branding policies by looking 
not at places but at people; thus, rather than trying to encourage tourism, for instance, we should be asking what tourism can do for the inhabitants.

Efe Sevin's chapter (Chapter 3) proposes a research agenda for computational approaches in place branding, highlighting two different domains for future enquiry. The first refers to changes in practice, arguing that as algorithm-based thinking in place development (evident in the concept of smart cities/ destinations) is increasingly adopted by city managers/marketers, then as a practice-driven field, place branding scholarship should also incorporate those changes into its research agendas. The second domain relates to consequent changes in the availability of data/analysis methods for researchers, as they increasingly gain access to larger and more diverse datasets on individual attitudes and behaviours, which may potentially replace traditional data-gathering methods or enable identification of previously undiscovered patterns across datasets. Nevertheless, Efe sounds a cautionary note that large datasets are not a substitute for a sound theoretical framework, and these computational approaches should be led by theory.

Andrea Insch's chapter (Chapter 4) aims to examine and clarify the concepts of participation and engagement in urban branding and to identify the forms that this can take for members of the local community. The chapter analyses previous research into this important aspect of place branding practice to dissect forms of participation and engagement and the mechanisms that can act as enablers and barriers to participation and engagement. Andrea concludes by arguing that the evolution of participatory approaches to the process of urban branding must move beyond a one-dimensional view, which is focused principally on including a wide range of participants, to a two-dimensional view that also enables their deep engagement in these ongoing and dynamic processes. It follows that future research on the governance of place branding, which is typically played out in multistakeholder environments, should embrace this perspective.

The final chapter of Part I (Chapter 5), by Eduardo Oliveira, Kristof Van Assche and Raoul Beunen, discusses the relationship between spatial planning and place branding, in terms of guiding the location of development and physical infrastructure and for promoting social, economic and ecologically sustainable development. They argue that planning and branding have the potential to work together in contributing to the integrated socioeconomic development and environmental sustainability of places, and that this contribution can only be effective if they are not isolated from the broader realms of decision making, and from each other. The chapter highlights the multidisciplinary roots of place branding research, and the need to draw from and 
synthesise these different disciplinary approaches if we are to obtain the fullest understanding of the concept.

\section{Contexts}

Part II brings together chapters that cover place branding and concomitant research agendas from a broad variety of contexts - e.g. academic, political, geographical, sporting, environmental and digital.

Chapter 6, by Aleks Vladimirov and Gary Warnaby examines place branding through the ever popular lens of behavioural economics. Specifically, they examine the potential of this academic discipline to explain the locational choices made by individuals (acting for their own ends, or on behalf of organisations they are part of) in response to the associated marketing/branding activities that are used to enhance the attractiveness of places by those responsible for their management. The focus here is on heuristics and biases - or the 'cognitive shortcuts' - that may influence decision making in terms of choosing where, for example, to live, work and invest. This is in contrast to neoclassical economists' view of 'homo economicus', making optimally rational decisions which deliver maximum personal utility. They conclude by indicating the potential for behavioural economics to influence how we research place branding in the future. In particular, it is a perspective that can help us understand how humans can make locational decisions that are not solely rooted in the rational pursuit of maximising financial opportunity, but can also be influenced by other perceived benefits inherent in the familiarity of our surroundings, including our social relationships and sense of belonging to places.

In Chapter 7, Adriana Campelo explores the role of cities in taking leadership on global agendas such as sustainability and climate change, and how this impacts on city branding. The chapter starts with discussion of the Resilient Cities programme, which is concerned with urban resilience and place making. Concepts relating to social-ecological systems theory are considered, and cities' initiatives in terms of climate change are examined. Adriana concludes by proposing how issues such as sustainability, resilience and carbon neutrality are an important new avenue for future research in place branding; this is especially salient in the light of Covid-19. How cities and countries are acting to deal with these ongoing challenges will affect their images and reputations for a long time into the future. This raises important and fundamental questions, such as how city branding can effectively foster resilience and embrace climate emergency action. 
Cecilia Cassinger, Andrea Lucarelli and Szilvia Gyimóthy consider the specifics of Nordic approaches to place branding in Chapter 8. They emphasise how 'the Nordic wave' provides not only a geographical context for work on place branding, but also a particular ideological mindset that can fashion distinctive approaches to concepts, strategies and tactics. They argue for a Nordic approach to place branding that sits between 'management' and 'critical' standpoints, and go on to articulate what this means in terms of global reflexivity and responsibility, legitimisation of place branding practices, and shifting geopolitical boundaries. In doing so, they invite us to question commonly held stereotypes of the Nordic, with their emphases on social welfare and peaceable coexistence, and instead highlight how such countries have their own troubled histories and ongoing issues relating to marginalisation in various forms.

In Chapter 9, Steve Millington, Chloe Steadman, Gareth Roberts and Dominic Medway turn to consider different scales as they relate to place branding literature and practice. Specifically, they explore 'the relative neglect of scalar tensions between the local and global, and the glocal and grobal'. They do this by analysing longitudinally the branding practices of one of the UK's leading football (soccer) teams, Manchester City, alongside the activities of its 'parent' organisation City Football Group, and the City of Manchester. They discuss the often complex interplay of factors that underpin the operation of a football club with global ambitions; drawing out how the local operations of the club are intertwined with the activities of its United Arab Emirates-based parent and the ambitions of the city's political elite to reframe Manchester as a future global city.

Switching back to the sustainability context raised, in part, in Chapter 7, Anette Therkelsen, Laura James and Henrik Halkier further examine the role of the United Nations Sustainable Development Goals (SDGs) in Chapter 10. They identify that the SDGs have left a mark on the rhetorical strategies of cities and countries, but that it remains to be seen how they will influence place development practices across the world in future. Areas for researchers to examine will be a balance of quick wins against long-term solutions, along with the challenge of aligning the SDGs with the multiple and often conflicting market interests of place branding. For example, the altruistic engagement of residents with sustainability issues may clash with the more competitive mindsets of other private and public stakeholders, who may favour short-term solutions to ensure a better position for a given town, city, region or nation in the enduring competition between places. 
In Chapter 11, Brendan James Keegan considers aspects of digital transformation in relation to place. Adopting a systematic literature review, he approaches this through a tripartite categorisation - or what he terms the 'trifecta' of place marketing, place making and place maintenance. Relevant examples that illustrate the potential of digital applications are mooted, including technologies that can alert residents to neighbourhood crime. While recognising the nascent status of much of the research in this area, Brendan points out that long-term studies into the role of digital applications in places are lacking. He proposes that future research considering the digitalisation of place should centre on three key areas: artificial intelligence, automation processes and social media sentiment analysis.

\section{Experience}

Part III draws together chapters concerned with how places are experienced and the implications of this for a place branding research agenda. Experience here covers concepts such as co-creation, authenticity, sensemaking and non-representational theory. However, in the first contribution to this part (Chapter 12) Jack Coffin moves away from a principally human focus to consider what places are like for nonhumans, and the implications of this for place branding research. As Jack notes, 'most scholars focus exclusively on the human experience of place'; but following a posthuman approach, this chapter challenges us to ask how animals, smart objects and other nonhumans might also experience places. This raises other important questions; not just how humans might affect nonhuman experiences of place(s), but also how nonhuman actors and actants can impact on human experiences in turn. Jack concludes the chapter by indicating how a posthuman research agenda may help engender a more ecological and equitable approach to place branding theory and, potentially, practice in the future.

In recent decades, the concept of co-creation has featured increasingly in marketing and other cognate disciplines, recognising as it does the significant role that consumers can play in the design of products and services. In Chapter 13, Jenny Rowley and Sonya Hanna consider the phenomenon as it relates to place branding. They highlight the different stakeholders that can be involved in the development of place brands, as well as the various ways in which this can take place. The significant potential for co-creation via social media and other online platforms is also highlighted, although Jenny and Sonya illustrate the importance of ensuring that user-generated content aligns with how the destination marketing organisation wishes to project the place. They conclude by presenting a number of foci for future research, including, perhaps most pertinently, further theoretical development of the distinction between a place 
stakeholder and customer and the consequences of this for the co-creation of place brands.

In Chapter 14, Maria Lichrou and Lisa O’Malley consider first how place branding practices with their all too common focus on the commodification of formulas for supposed success, including the serial reproduction of cultural attractions, can have a homogenising effect on places, whilst at the same time fuelling a touristic desire for greater place authenticity. They explore how more recent marketing thinking opens up new possibilities for action, facilitating experience co-creation, the realisation of value and the potential for existential authenticity. Such an approach suggests that the marketing strategy of tourism places cannot simply be determined in advance of the tourist's lived place experience. This suggests that future research and practice would do well to consider how tourism places might produce the resources out of which value can be created. From this, the place brand is likely to emerge as a symbolic resource that serves to more effectively mediate and integrate marketing activities.

Chapter 15 by Laura Reynolds and Nicole Koenig-Lewis discusses how place brand meanings are developed and transferred across different stakeholder groups through stakeholder engagement. This is at the heart of the participatory and collaborative place branding processes that have been an important theme in recent place branding research. Using a case study based on stakeholder interviews, Laura and Nicole utilise the notions of sensemaking and sensegiving to examine how people form and convey meanings assigned to the places they live, work and invest in; and by adding a sensefiltering layer, consider how influence can be shaped by stakeholders' possession of resources and leadership. In this regard, they offer an explanation for managing complexity, transition and change which is at the heart of a participatory approach to place branding.

In Chapter 16, Simon Cryer argues for an approach to place branding that captures more fully the range of our senses and our experience in place. He considers how a non-representational approach can be drawn on to investigate 'the relationships between place, space, the senses, and life'. Simon invites us to reflect on how place branding might be approached from alternative angles, or from the perspective of those elements of place that might frequently be overlooked. There is perhaps a signal here to think not only about how place branding can take better account of the ways in which people might experience place in non-representational or more-than-representational ways, but also how the activity of place branding itself might engage more effectively with 
its audiences by using multisensory approaches that move beyond the visual media on which it appears so heavily reliant.

\section{Creativity}

Part IV, focused on creativity, is the shortest part, containing as it does only three chapters. However, it was clear from the outset that these three contributions were very distinct from the rest of the submissions and therefore deserved their own separate billing in the running order. The first two chapters herein focus on human creativity in the visual forms of light and art, and consider the implications of this for place branding research and practice. And, aside from its subject content, the final chapter by Stephen Brown belongs in this part as much for its creative approach to academic writing. It is also a natural and fitting sign off to this book.

Chapter 17 by Tim Edensor builds on his already extensive work on light festivals, and considers whether they homogenise or enhance place. He presents two opposing and, to a certain extent, scalar perspectives. On the one hand there are the typically larger light displays that critics assert can be bland, environmentally unsustainable and lacking in place specificity. On the other hand, our attention is directed to increasingly popular smaller, local light festivals that are being used to undergird place identity. Overall, a clear message emerging from Tim's chapter is that place branding research would do well to examine further how the creative, collaborative and sometimes experimental uses of illumination can be a powerful tool for generating exciting place potentialities.

Mihalis Kavaratzis and Gary Warnaby consider in Chapter 18 how to engage creatively in place branding research. They recognise the increasing attention being paid to the affective associations that places hold, and link these to more artistic modes of enquiry. Drawing on their own experiences of exhibiting creative work relating to their own research into place (Mihalis's visual art and poetry, and Gary's photo-essays), they argue for an approach to place branding research which can facilitate arts-based practices. For this to work, they emphasise the importance of having a clear justification for the approach taken, a relevant agenda of themes that can be tackled and a clear sense of the different methods that can be adopted.

As noted above, in the final chapter of Part IV (Chapter 19), and of the book, Stephen Brown takes a creative and 'almost-autobiographical' approach in considering place marketing and place branding and what the future might hold. The conclusion is that such activity has 'peaked', and that less place 
marketing is needed rather than more. Stephen's approach is undoubtedly pitched as deliberately provocative, or as he terms it 'irreverent and ridiculous by turns', yet beneath its welcome humour his chapter does pose some important and uncomfortable questions for place branding research and practice as we move forward - What and who are we doing it for? Who benefits and who loses from such activity? And ultimately, echoing a challenge from Medway et al. (2015), 'Are we wasting our time'?

What this book reveals throughout its chapters is that it is not yet time to shut up shop and to give up entirely on place branding. However, reprising ideas discussed above, we are perhaps at a point in time where a logical and sensible step is to push the 'reset button' on such activity and fully (re)consider its purpose and goals. We believe the following chapters serve as an excellent start to this rebooted journey, providing a wealth of creative and innovative suggestions from our contributors on how place branding might be done, thought about and researched differently in the future.

\section{Notes}

1. See for example: www.ipsos.com/sites/default/files/20-03-60_anholt-ipsos_place branding.pdf.

2. See for example: www.ipsos.com/en-us/news-polls/Germany-Retains-Top.

3. Those unfamiliar with this reference should watch Marlon Brando's performance as Terry Malloy in the 1954 film On the Waterfront.

4. The full quote, as reported in The New York Times (31 October 1971), and attributed to Lyndon Johnson's comments regarding FBI Director J. Edgar Hoover, is: 'It's probably better to have him inside the tent pissing out, than outside the tent pissing in'.

\section{References}

Bathelt, H., Malmberg, A. and P. Maskell (2004), 'Clusters and knowledge: Local buzz, global pipelines and the process of knowledge creation', Progress in Human Geography, 28 (1), 31-56.

Braun, E., Kavaratzis, M. and S. Zenker (2013), 'My city - my brand: The different roles of residents in place branding', Journal of Place Management and Development, 6 (1), 18-28.

Constantin, M., Saxon, S. and J. Yu (2020), 'Reimagining the $\$ 9$ trillion tourism economy - what will it take?', McKinsey and Company, accessed 21 August 2020 at: www.mckinsey.com/industries/travel-logistics-and-transport-infrastructure/our -insights/reimagining-the-9-trillion-tourism-economy-what-will-it-take. 
Heidegger, M. (2001), 'Building, dwelling, thinking', in M. Heidegger (trans. Albert Hofstadter), Poetry, Language, Thought, New York: Perennial, pp. 141-59.

Ivey, P. (2020), 'London in lockdown: Hidden gems we've discovered during quarantine', ES Homes and Property, 28 May, accessed 28 August 2020 at: www .homesandproperty.co.uk/property-news/london-hidden-gems-lockdown-a138581 .html.

Kaplan, M. D., Yurt, O., Guneri, B. and K. Kurtulus (2010), 'Branding places: Applying brand personality concept to cities', European Journal of Marketing, 44 (9/10), 1286-304.

Lichrou, M., Kavaratzis, M. and M. Giovanardi (2018), 'Introduction', in M. Kavaratzis, M. Giovanardi and M. Lichrou (eds), Inclusive Place Branding: Critical Perspectives on Theory and Practice, Abingdon: Routledge, pp. 1-10.

Mathers, M. (2020), 'Cornwall tourist chief condemns sign telling visitors to " $\mathrm{f}^{\star \star} \mathrm{k}$ off", The Independent, 6 July, accessed 21 August 2020 at: www.independent.co.uk/news/ uk/home-news/cornwall-tourism-sign-a30-bodmin-seaside-lockdown-a9603961 .html.

Medway, D., Swanson, K., Neirotti, L. D., Pasquinelli, C. and S. Zenker (2015), 'Place branding: Are we wasting our time? Report of an AMA special session', Journal of Place Management and Development, 8 (1), 63-8.

Medway, D. and G. Warnaby (2014), 'What's in a name? Place branding and toponymic commodification', Environment and Planning A, 46 (1), 153-67.

Medway, D. and G. Warnaby (2017), 'Multisensory place branding: A manifesto for research', in A. Campelo (ed.), Handbook on Place Branding and Marketing, Cheltenham, UK and Northampton, MA, USA: Edward Elgar Publishing, pp. 147-59.

Monk, Z. (2020), 'UK staycation boom looks set to continue into 2021, new research finds', Boutique Hotelier, 14 August, accessed 28 August 2020 at: www .boutiquehotelier.com/uk-staycation-boom-looks-set-to-continue-into-2021-new -research-finds/.

Nikolic, I. (2020), 'British workers are the most reluctant in Europe to come back to the office because of second wave fears, says study as Business Secretary Alok Sharma calls for return to the workplace', Mail Online, 25 August, accessed August 28 at: www.dailymail.co.uk/news/article-8661463/UK-workers-reluctant-return-office -second-wave-fears-says-study.html.

Oliveira, E. and G. Ashworth (2017), 'A strategic spatial planning approach to regional branding: Challenges and opportunities', in A. Campelo (ed.), Handbook on Place Branding and Marketing, Cheltenham, UK and Northampton, MA, USA: Edward Elgar Publishing, pp. 22-40.

Partridge, J. (2020), 'UK office workers slower to return to their desk after Covid', The Guardian, 5 August, accessed 27 August 2020 at: www.theguardian.com/business/ 2020/aug/05/uk-office-workers-slower-to-return-to-their-desk-after-covid.

Pinch, S., Henry, N., Jenkins, M. and S. Tallman (2003), 'From "industrial districts" to "knowledge clusters": A model of knowledge dissemination and competitive advantage in industrial agglomerations', Journal of Economic Geography, 3 (4), 373-88.

Tuan, Y.-F. (1974), Topophilia: A Study of Environmental Perception, Attitudes, and Values, Englewood Cliffs, NJ: Prentice Hall.

Warnaby, G. and D. Medway (2013), 'What about the "place" in place marketing?', Marketing Theory, 13 (3), 345-63. 